\title{
MITYCZNO-SYMBOLICZNY PARADYGMAT ETNICZNOŚCI JOHNA A. ARMSTRONGA
}

\author{
JOHN A. ARMSTRONG'S MYTH-SYMBOL \\ PARADIGM OF ETHNICITY
}

\begin{abstract}
The theme of this article is John Alexander Armstrong's mythsymbol paradigm of ethnicity as a polemic with the modernist theory of nationalism, assuming duplication of the nation in relation to nationalism. According to Armstrong, more important for the survival of the nation than political and economic issues, is creating and updating of mythological complex, able to maintain stability of the nation. Reminding ethnicity paradigm seems to be important in the context of the events in Ukraine and the process of creating a new political mythology, reinforcing the Ukrainian national identity.
\end{abstract}

Key words: ethnicity; myth; identity; nationalism; nation, John A. Armstrong

\section{Streszczenie}

Tematem artykułu jest mityczno-symboliczny paradygmat etniczności Johna Alexandra Armstronga, jako polemika z modernistyczną teorią nacjonalizmu, zakładającą wtórność narodu w stosunku do nacjonalizmu. Według Armstronga ważniejsze dla przetrwania narodu były nie kwestie polityczno-gospodarcze, lecz stworzenie i aktualizacja kompleksu mitologicznego, zdolnego do podtrzymywania trwałości narodu. Przypomnienie paradygmatu etniczności wydaje się istotne w kontekście wydarzeń na Ukrainie i obserwowanego tam procesu tworzenia nowej mitologii politycznej, wzmacniającej ukraińską tożsamość narodową.

ANNA SIEWIERSKA-CHMAJ,

Słowa kluczowe: etniczność; mit; tożsamość; nacjonalizm; naród; John A. Armstrong

Instytut Badań nad Cywilizacjami WSliz w Rzeszowie. Correspondence: asiewierska@wsiz.rzeszow.pl

This is an Open Access article distributed under the terms of the Creative Commons Attribution 3.0 PL License (creativecommons.org/licenses/by/3.0/pl/), which permits redistribution, commercial and non-commercial, provided that the article is properly cited. (c) The Author(s) 2015.

Publisher: Institute of Slavic Studies PAS [Wydawca: Instytut Slawistyki PAN] 
l eden z ukraińskich historyków, Ołeksandr Zinczenko, nazwał to, co komunizm uczynił z jego krajem „amputacją pamięci”, „trepanacją czaszki i wygrzebaniem mózgu łyżką" (Pogorzelski, 2014, s. 221). To dosadne porównanie dobrze oddaje sytuację Ukrainy po uzyskaniu niepodległości w 1991 roku - brak jakiejkolwiek pamięci społecznej, która mogłaby trwale zjednoczyć głęboko podzielone społeczeństwo. Ten brak mitycznosymbolicznego kapitału, który próbowano wypełnić narzuconą przez władze oficjalną polityką historyczną ${ }^{1}$, był poważną przeszkodą na drodze do umacniania idei nowego państwa ukraińskiego, ale przede wszystkim uniemożliwiał istnienie wewnętrznie zintegrowanego narodu ukraińskiego. Obecnie jednak Euromajdan i wojna na wschodzie stały się centralnymi punktami nowej mitologii politycznej Ukrainy, dostarczając symboli, obrazów i mitów, wypełniających aksjologiczną pustkę. Poprzez te obrazy i symbole, mit Euromajdanu zaczął opowiadać swoją własną historię. Analiza treści ukraińskich mediów i portali społecznościowych dostarcza wyraźnych dowodów, że ofiary Euromajdanu szybko stały się nowymi bohaterami narodu ukraińskiego, stymulując jego wewnętrzną spójność, dostarczając wzorów postępowania i budując nowy system wartości. Wrogowie zaś zaczęli utożsamiać metafizyczne Zło, które można pokonać solidarnością społeczną, wyzwoloną dzięki politycznej mitologii, wzmacniającej tożsamość narodową. Proces tworzenia się ukraińskiej tożsamości narodowej w oparciu o polityczne mity, który można teraz obserwować na bieżąco, wskazuje na trafność mityczno-symbolicznego paradygmatu Johna Alexandra Armstronga, wyłożonego najpełniej w pracy Nations before Nationalism. Nie tylko w kontekście Ukrainy paradygmat Armstronga wart jest przypomnienia.

Punktem wyjścia dla rozważań Johna A. Armstronga o narodzie i nacjonalizmie jest transakcyjna koncepcja granicy norweskiego antropologa Fredrika Bartha, który pojmował ją jako pewien sposób organizacji społecznej, z którego z kolei wynika struktura zachowań i relacji społecznych. Jak pisze Barth:

stabilne międzyetniczne relacje są możliwe przy założeniu, że w strukturę interakcji wbudowane są następujące zbiory: zbiór zasad rządzących sytuacjami kontaktu i pozwalających na artykulację w niektórych sektorach czy zakresach ludzkiego działania oraz zbiór zakazów dotyczących sytuacji społecznych, zapobiegających międzyetnicznym interakcjom w innych sektorach i stąd też chroniących części kultury przed konfrontacją z innymi kulturami i przed modyfikacjami (Barth, 2006, s. 355).

Granice nie implikują zatem braku zależności, przeciwnie, są istotnym i niezbędnym elementem budowy trwałych systemów społecznych. Barth odrzucił hipotezę jakoby granice społeczne wynikały z różnic kulturowych, stanowiących trwałe, substancjalne charakterystyki grup społecznych i przyjąt, że przynależność do grupy nie wynika z obiektywnych cech kulturowych, a zatem i „zawartość” granicy może ulec zmianie. Zdaniem norweskiego antropologa istnienie granicy jest integralnym elementem podtrzymywania tożsamości grupowej i kontynuacji rozróżnienia na „swoich" i „obcych”. Według Bartha,

"drastyczna redukcja różnic między grupami etnicznymi nie wiąże się w żaden prosty sposób z redukcją organizacyjnej doniosłości tożsamości etnicznych lub z załamaniem się procesów sprzyjających utrzymywaniu granic etnicznych (Barth, 2006, ss. 371-372).

O mitotwórczej działalności władz Ukrainy pisał m.in. John-Paul Himka: „W czerwcu 2007 roku oficjalnie obchodzono stulecie urodzin dowódcy UPA Romana Szuchewycza. Wkrótce potem ukraińska poczta wydrukowała znaczek na cześć Szuchewycza, na którym znajdowały się zarówno emblematy OUN, jak i UPA. Niedługo później Juszczenko mianował Szuchewycza pośmiertnie Bohaterem Ukrainy. (...) Tuż przed opuszczeniem urzędu na początku 2010 roku, Juszczenko mianował także Stepana Banderę, przywódcę radykalnego skrzydła OUN, odpowiedzialnego za czystki etniczne w czasie Holocaustu, pośmiertnie Bohaterem Ukrainy" (Himka, 2012). 
To granica między grupami utrwala więzi etniczne, a nie "rzeczy kulturowe", które ta granica otacza.

John Armstrong uważa, iż takie podejście do fenomenu etniczności oznaczałoby przyjęcie, że jego podstawą jest wykluczenie i brak komunikacji z grupami obcych:

Moje podejście do zjawiska etniczności podkreśla jego właściwości graniczne zamiast „esencji" tożsamości etnicznej, co czynili niektórzy badacze. Tożsamość, w moim podejściu, jest intensywnie oddziałującym zjawiskiem i jako takie stanowi wartość samą w sobie (...). Wiele grup etnicznych rozróżnia jedynie ich postrzeganie, tak przez członków danej wspólnoty, jak i obcych, co jest sformułowane w treści mitycznej (Armstrong, 1982, s. 291).

Podejście graniczne rezygnuje z idei wyłącznego terytorium dla każdej grupy etnicznej, większą wartość przypisując etniczności jako kontinuum zbiorowości społecznych, zwłaszcza klas i wspólnot religijnych. Każda z tych zbiorowości ma tendencję do zmian na przestrzeni czasu, zwłaszcza grupy etniczne i religijne, ale według Armstronga, zwolennika długiego trwania² tożsamości narodowych, to właśnie świadczy o ich sile. Amerykański historyk i politolog wskazuje na przypadek przednowoczesnego islamu i chrześcijaństwa, podkreślając, że

ich wspólne pochodzenie, jak również ich bliskość geograficzna sprawiły, że cywilizacja islamska i chrześcijańska były dla siebie nawzajem głównymi punktami odniesienia. Stało się tak, ponieważ obie cywilizacje przypominały rozmachem grupy etniczne, które często określają się przecież poprzez odniesienie do grup obcych (Armstrong, 1982, s. 285).

Anthony D. Smith zauważa, iż pozornie mogłoby się wydawać, że w "sercu granicznej koncepcji Armstronga jest kulturowa pustka", której częściowo udało się uniknąć Barthowi w koncepcji transakcyjnej, ponieważ odnosił się do bardziej ogólnych, generalnych tożsamości jednostek. W rzeczywistości jednak, twierdzi autor Nacjonalizmu Armstrong

ma na celu dostarczenie innych treści kulturowych - narodowych mitów, symboli i komunikacji. Tak jak Barth, Armstrong jest przekonany, że symbole są istotne dla trwałości etnicznej; zwłaszcza symbole językowe działają jak etniczna straż graniczna, wyznaczająca granicę grupy.

Ale, aby były skuteczne i miały wydźwięk społeczny, symbole wymagają ciągłego przetwarzania w procesie komunikacji (Smith, 2015, s. 166).

Armstrong jest przeciwnikiem modernizacyjnych teorii nacjonalizmu, akcentujących nowoczesny charakter tego zjawiska i opisujących naród jako twór powstały w wyniku procesu przejścia od tradycyjnego do nowoczesnego społeczeństwa. Wskazywanie na industrializację i stosunki społeczno-gospodarcze, jako główne przyczyny rozwoju nacjonalizmu, uważa za poważny błąd. Twierdzi, że nowoczesny nacjonalizm jest częścią długiego cyklu świadomości etnicznej; tylko longue durée pozwala znaleźć wyjście ze ślepej uliczki, do której doprowadziła obsesja na punkcie nowoczesności nacjonalizmu. Nie ma cudownego pojawienia się narodu w czasie Rewolucji Francuskiej, jest natomiast długi proces ewolucji. Amerykański badacz nacjonalizmu wchodzi tym samym w dyskusję z modernistami (Ernest Gellner, Eric Hobsbawm i in.) i ich koncepcją wtórności narodu w stosunku do nacjonalizmu.

\section{-....}

2 Odnoszę się do długiego trwania (la longue durée), jako terminu zaproponowanego przez Fernanda Braudela i francuską szkołę Annales dla określenia perspektywy czasowej, w której dokonują się zmiany cywilizacyjne i religijne. W koncepcji Braudela, którą zdaje się podzielać John A. Armstrong, większość bieżących wydarzeń politycznych nie ma znaczenia dla istoty przemian, a w dłuższej perspektywie jest wręcz nieistotna. Bieżące wydarzenia polityczne są najpłytszą warstwą historii, warstwę głębszą stanowią procesy gospodarcze, również niemające sprawczej roli. Poziom najgtębszy i najważniejszy tworzą przemiany cywilizacyjne, kulturowe i religijne i to one są najbardziej istotne dla zrozumienia dziejów świata (Braudel, 1999, 2006). 
Armstrong proponuje w zamian paradygmat etnosymboliczny ${ }^{3}$, kładący nacisk na długoterminowe badanie wzorów społecznych i kulturowych. Smith tak definiuje perspektywę etnosymboliczną:

Jedynie prowadząc badania przez kilka pokoleń, a nawet kilka wieków, badacze mogą ukazywać całościowe związki pomiędzy przeszłością, teraźniejszością i przyszłością oraz miejsce etni i narodów w historii. Umożliwia nam to uniknięcie anachronizmu „retrospektywnego nacjonalizmu", a więc doszukiwania się w warunkach i polityce poprzednich epok zbiorowych celów i nacjonalistycznych dążeń właściwych dla współczesności, a jedynie umożliwia ukazywanie wielości zróżnicowanych form zbiorowej tożsamości kulturowej typowych dla wcześniejszych wieków (Smith, 2007, ss. 80-81).

Smith ceni przede wszystkim fakt, że etnosymbolizm zwraca uwage na to, jak wcześniejsze formy zbiorowej tożsamości mogą wpływać na rozwój narodów, uwzględniając przy tym wszelkie przerwy i brak ciągłości historycznych danych. Według Smitha szczególnie ważne jest właśnie studium Johna Armstronga Nations before Nationalism.

Wydaje się, że głównym celem analizy Armstronga jest dotarcie do subiektywnych, symbolicznych i socjokulturowych czynników kształtujących tożsamość etniczną. Tylko wniknięcie w wewnętrzny świat nacjonalizmu i poznanie mityczno-symbolicznego zaplecza narodów, pozwala, według tego badacza, na zrozumienie kierujących nimi emocji, które często stają się przecież przyczyną konfliktów. Armstrong podkreśla także, że granice pomiędzy grupami etnicznymi są nawet bardziej symboliczne niż realne, dlatego dużo lepiej niż linie narysowane na mapie, wyrażają je słowa.

Słowa te, są szczególnie skuteczne, jako sygnalizacja uliczna, ostrzegająca członka wspólnoty przed intruzem zbliżającym się do bariery odgradzającej jedną grupę od drugiej (Armstrong, 1982, ss. 7-8).

Równie ważna jest rola mitu jako elementu zapewniającego ciągłość i trwałość etniczności. Dla Armstronga, podobnie jak wcześniej dla Mircei Eliadego i Josepha Campbella, recytowanie mitycznych opowieści w miejscach publicznych miało znaczący wpływ na wzbudzenie świadomości etnicznej wśród członków grupy, dawało im poczucie „wspólnego losu", podkreślało solidarność przed obcą siłą, poprzez wzmocnienie postrzegania granicy (Armstrong, 1982, s. 9). Armstrong szczegółowo opisuje różne warianty symboli i mitów chrześcijańskich i islamskich i ich wpływ na sferę polityczną. Dowodzi to, według niego, trwałości symboli politycznych właśnie w kategorii długiego trwania, w innym wypadku bowiem ich wpływ nie byłby tak znaczący. Należy zaznaczyć, choć Armstrong nie pisze tego wprost, że każdy symbol i każdy mit może się stać politycznym w momencie, gdy zaczyna pełnić funkcje polityczne, np. legitymizując władzę, czy też wzmacnia wewnętrzną spójność grypy w obliczu zewnętrznego wroga.

Smith zauważa, że szczególne znaczenie dla perspektywy Armstronga ma rola i częstotliwość konstytutywnego mitu politycznego, mythomoteur, siły napędowej określanej jako to, co podtrzymuje ustrój i pozwala na tworzenie tożsamości (Smith, 2015, ss. 166 167). Smith w Etnicznych źródłach narodów definiuje mythomoteur jako zespolone i dopracowane w szczegółach mity, dostarczające etnicznej wspólnocie wszechogarniającej ramy znaczeń, nadającej sens jej doświadczeniom i określającej jej istotę.

"Odkrycie” lub „wynalezienie” historii (...) jest sprawą honoru narodowego i zbiorowego wysitku. Śledząc naszą historię to "my" odkrywamy (lub "odkrywamy ponownie"), kim jesteśmy, skąd przyszliśmy, kiedy powstaliśmy, kim byli nasi przodkowie, kiedy byliśmy wielcy

......

3 Armstrong najpełniej opisał ten paradygmat w Encyklopedii nacjonalizmu (Armstrong, 2001). 
i wspaniali, kto był naszym bohaterem, dlaczego spotkał nas upadek... Jednakże ponowne odkrycie "narodowej jaźni" nie jest kwestią akademicką; to nagląca kwestia praktyczna, stale powracająca i kontrowersyjna, która jest sprawą życia i śmierci dla nacjonalistycznego projektu kreowania narodu (Smith, 2009, s. 218).

Ta mitologiczno-symboliczna perspektywa etniczności, przyjęta przez Smitha a zakorzeniona, jak się wydaje, właśnie w etnosymbolicznym paradygmacie Armstronga, pozwala lepiej zrozumieć fundamenty współczesnych narodów i zjawisko nacjonalizmu.

Książka Nations before Nationalism została opublikowana w 1982 roku, jednak John A. Armstrong zręby swojego mityczno-symbolicznego paradygmatu etniczności stworzył dużo wcześniej, badając zjawisko nacjonalizmu ukraińskiego. Należy zaznaczyć, że prowadził badania nacjonalizmu ukraińskiego w okresie dekolonizacji imperiów europejskich, gdy nacjonalizm miał pozytywne konotacje, jako ideologia wyzwolenia narodowego. To istotna uwaga, ponieważ obecnie głównym zarzutem w stosunku do prac tego autora jest idealizowanie nacjonalizmu integralnego i niedostrzeganie niebezpieczeństwa, które on niesie4. Tymczasem Armstrong w pracy Ukrainian Nationalism, 1939-1945 tłumaczył, że

Integralny nacjonalizm był gorączką, która chwyciła najbardziej aktywne elementy Ukrainy w poprzednim pokoleniu, ale łatwiej to zrozumieć i być może zaakceptować w tym kraju niż w innych, które miały więcej możliwości wyrażania siebie poprzez rozwój państwa, w oparciu o prawo (Armstrong, 1963, s. 23).

Celem Armstronga nie była zresztą analiza działalności OUN i UPA, lecz pokazanie nacjonalizmu ukraińskiego jako reakcji obronnej na nacjonalizmy zagranicznych sąsiadów (Armstrong, 1963, s. 8). Interesowała go przede wszystkim ideologia narodowa, wykorzystująca historyczne mity, umacniające czy wręcz kreujące tożsamość narodową Ukraińców. Armstrong dostrzegał siłe politycznego mitu, którego jądrem były, potraktowane wybiórczo, wydarzenia z przeszłości Ukrainy, tworzywem twórczość Tarasa Szewczenki, Iwana Franko i Mykoły Kostomarowa a aktualizacją i reinterpretacją, działalność Mychajła Hruszewskiego.

Hruszewskiego, jako przewodniczącego Ukraińskiej Centralnej Rady, a przede wszystkim autora kilku książek na temat historii Ukrainy i literatury ukraińskiej, uznawał Armstrong za „ojca ukraińskiego nacjonalizmu” (Armstrong, 1963, s. 7). Dla każdej wielkiej zbiorowości mit jest nie tylko opowieścią, ale czymś realnie istniejącym, wpływającym na przyjmowane postawy i podejmowane decyzje, jest źródłem powszechnie podzielanej wiedzy. Jako taki jest także jądrem tożsamości narodowej, naród bez mitu nie może istnieć. Hruszewski zdawał sobie z tego sprawę, dlatego jego Historia Ukrainy-Rusi była dziełem tyleż historycznym, co mitologicznym. Zbiorowa pamięć jest repozytorium politycznych mitów, historyk snuł zatem opowieść o źródłach narodu ukraińskiego na terenie Rusi, nawet wbrew historycznym faktom. Stworzył mit założycielski Ukrainy, sankcjonując prawo Ukraińców do ziemi, na której mieszkali.

Według Armstronga ukraiński nacjonalizm zrodził się w odpowiedzi na XIX-wieczny nacjonalizm niemiecki i polskie ruchy niepodległościowe w Galicji. Wydaje się jednak, że najbardziej interesuje go nie wpływ Fichtego, czy Herdera na Dmytro Doncowa, Stepana Banderę czy Romana Szuchewycza, ale właśnie proces zaczarowywania świata i mitolo-

4 Przeciwnikiem mitologizowania nacjonalistycznych organizacji ukraińskich OUN i UPA jest m.in. John-Paul Himka, który zarzuca pracom Armstronga anachronizm i opieranie się na niepełnych źródłach. Rzeczywiście Armstrong badał ukraiński nacjonalizm prowadząc wywiady z żyjącymi członkami OUN i UPA i analizując dokumenty tych organizacji. Nie znał natomiast historii zbrodni na Polakach i Żydach, których dopuścili się nacjonaliści ukraińscy (Himka, 2011). 
gizowania rzeczywistości przez ideologów ukraińskiego nacjonalizmu. Stopniowe budowanie tożsamość narodu, pokazywanie jego wyjątkowości, polityczna mitologizacja czasu i przestrzeni są dla Armstronga ważniejsze niż polityczna działalność OUN czy UPA.

Jeżeli kiedykolwiek istniała grupa gotowa walczyć z trudnościami, zdawałoby się niemożliwymi do pokonania, była to OUN. Kilka tysięcy niedoświadczonych i niedostatecznie wyposażonych młodych ludzi nie tylko wyruszało na Wschód, aby zmienić gigantyczny system radziecki, lecz także odważyło się rzucić wyzwanie, zdawałoby się niezwyciężonej, niemieckiej machinie wojennej. W świecie, gdzie strach w obliczu ataku tyranii stał się normalnością, tego rodzaju waleczność równoważy wiele wad

- tłumaczy Armstrong (Armstrong, 1963, s. 283), widząc w OUN i UPA ruch "romantyczny" i „woluntarystyczny”.

Przekonanie Armstronga o konstytuującej roli mitu politycznego podziela wielu badaczy, zwłaszcza zajmujących się Ukrainą i innymi państwami postsowieckimi, które wciąż nie zakończyły procesu budowania tożsamości narodowej. Taras Kuzio twierdzi, że

Tylko nacjonalizm może zapewnić alternatywny zestaw mitów i symboli, które byłyby w stanie zastąpić zdyskredytowane radzieckie i marksistowsko-leninowskie dziedzictwo i utrzymać razem zatomizowane społeczeństwo (...). Nacjonalizm daje regionalnym elitom szytą na miarę legitymizację ich dążeń do suwerenności w czasach rozpadu imperium (Kuzio, 1994, ss. 83-84).

Podobnego zdania jest Alexander Motyl (Motyl, 2010, s. 9) czy Mykola Riabczuk, którzy podkreślają, że Ukraina, jako młode państwo, szczególnie potrzebuje politycznych mitów konsolidujących, nawet jeśli mity te są kontrowersyjne, jak zresztą spora część politycznych mitów innych narodów (Riabczuk, 2010).

Jak twierdzi Pål Kolstø, „, bezpośrednim wkładem Armstronga do badań nacjonalizmu, było stworzenie przez niego osobnej szkoły badawczej, nazywanej etnosymbolizmem" (Kolstø, 2015, s. 180), do której zalicza się także Johna Hutchinsona i Anthony'ego D. Smitha. Steven Grosby dodaje, że dla Armstronga „analizy koncentrujące się przede wszystkim na funkcjonowaniu nowoczesnego rynku i relacjach władzy były dalece niewystarczające dla zrozumienia pojęcia narodu" (Grosby, 2015, ss. 183-184), ostro odrzucał bowiem tezę o dominującej roli interesów materialnych w procesie tworzenia się ludzkich zbiorowości (Armstrong, 2001, s. 199).

Międzypokoleniowa ciągłość tożsamości narodowej zależała, według Armstronga, od kompleksu mitów, które wykraczają poza czas i przestrzeń.

„Jak efektywne są konkurencyjne struktury mityczne w promowaniu stabilnego systemu politycznego zależy od pojemności mitów i ich zdolności do wypierania mitów tworzących odmienny system polityczny (Armstrong, 1982, s. 167).

W etnosymbolicznym paradygmacie etniczności mit, symbol, komunikacja i zbiór postaw są zwykle ważniejsze dla długiego trwania narodu, niż czynniki czysto materialne. Przypadek Ukrainy zdaje się potwierdzać tezy stawiane przez Johna Alexandra Armstronga. 
Armstrong, J. A. (1963). Ukrainian nationalism, 1939-1945. New York: Columbia University Press.

Armstrong, J. A. (1982). Nations before nationalism. Chapel Hill, N. C.: University of North Carolina Press.

Armstrong, J. A. (1997). Religious nationalism and collective violence. Nations and Nationalism, 3(4), 597-606. http://doi.org/10.1111/j.1354-5078.1997.00597.x

Armstrong, J. A. (2001). Myth and symbolism theory of nationalism. W A. S. Leoussi (Red.), Encyclopaedia of nationalism. New Brunswick: Transaction Publishers.

Barth, F. (1969). Ethnic groups and boundaries. Boston: Littlle, Brown and Co.

Barth, F. (2006). Grupy i granice etniczne: Społeczna organizacja różnic kulturowych. W M. Kempny \& E. Nowicka (Red.), Badanie kultury: Elementy teorii antropologicznej. Kontynuacje. Warszawa: PWN.

Bottici, C. (2007). A philosophy of political myth. New York: Cambridge University Press.

Braudel, F. (1999). Historia i trwanie. (B. Geremek, Tłum.). Warszawa: Czytelnik.

Braudel, F. (2006). Gramatyka cywilizacji. (H. Igalson-Tygielska, Tłum.). Warszawa: Oficyna Naukowa.

Gellner, E. (1991). Narody i nacjonalizm. (T. Hołówka, Tłum.). Warszawa: Państwowy Instytut Wydawniczy.

Grosby, S. (2015). Myth and symbol: The persistence of ethnicity and religion: John Armstrong and nationality. Nations and Nationalism, 21(1), 182-186. http://doi.org/10.1111/ nana. 12107

Himka, J.-P. (2011). Collaboration and or resistance: The OUN and UPA during the War. Ukrainian Jewish Encounter Shared Narrative Series: Conference on Issues Relating to World War II, Potsdam, 27-30 June 2011. Pobrano 5 lutego 2015, z https://www. academia.edu/577915/Collaboration_and_or_Resistance_The_OUN_and_UPA_during_ the_War

Himka, J-P. (2012). Challenging the myths of twentieth-century Ukrainian history, The convolutions of historical politics. Pobrano 5 lutego 2015, z https://www.academia. edu/2033835/_Interventions_Challenging_the_Myths_of_Twentieth-Century_Ukrainian_History_

Hobsbawm, E. (2010). Narody i nacjonalizm po 1780 roku. (J. Maciejczyk \& M. Starnawski, Tłum.). Warszawa: Wydawnictwo Difin.

Kolstø, P. (2015). John Armstrong: Typologies and grand narratives. Nations and Nationalism, 21(1), 177-181. http://doi.org/10.1111/nana.12108

Kuzio, T. (1994). Ukrainian nationalism. Journal of Area Studies, 2(4), 79-95. http://doi. org/10.1080/02613539408455708

Motyl, A. (2010). Ukraine, Europe, and Bandera. Cicero Foundation Great Debate Paper, (10/05).

Pogorzelski, P. (2014). Barszcz ukraiński. Gliwice: Helion.

Riabczuk, M. (2010). Bandera's controversy and Ukraine's future. Russkii vopros, (1). Pobrano 16 stycznia 2015, z http://www.russkiivopros.com/?pag=one\&id=315\&kat=9\&c sl=46\#_edn16

Siewierska-Chmaj, A. (2009). Mitologia polityczna jako fundament ideologii: Próba analizy. W A. Siewierska-Chmaj, J. Chłopecki i in., Przekazy polityki. Kraków, Rzeszów, Za- 
mość: Konsorcjum Akademickie Wydawnictwo WSE w Krakowie, WSliZ w Rzeszowie i WSZiA w Zamościu.

Smith, A. D. (2007). Nacjonalizm. (E. Chomicka, Tłum.). Warszawa: Sic!

Smith, A. D. (2009). Etniczne źródła narodów. (M. Głowacka-Grajper, Tłum.). Kraków: Wydawnictwo Uniwersytetu Jagiellońskiego.

Smith, A. D. (2015). "Nations before nationalism"? Myth and symbolism in John Armstrong's perspective. Nations and Nationalism, 21(1), 165-170. http://doi. org/10.1111/nana.12109 